\title{
VOLUMETRIC ASSESSMENT OF AIRBORNE INDOOR AND OUTDOOR FUNGI AT POULTRY AND CATTLE HOUSES IN THE MAZANDARAN PROVINCE, IRAN
}

\author{
Hatef AJOUDANIFAR ${ }^{1}$, Mohammad T. HEDAYATI ${ }^{2}$, Sabah MAYAHI ${ }^{2}$, Alireza KHOSRAVI ${ }^{3}$, \\ and Bita MOUSAVI ${ }^{2}$
}

Department of Mycology and Parasitology, Science and Research Branch, Islamic Azad University, Tehran ${ }^{l}$, Department of Medical Mycology and Parasitology, School of Medicine, Mazandaran University of Medical Sciences, Sari ${ }^{2}$, Mycology Research Centre, Faculty of Veterinary Medicine, University of Tehran, Tehran ${ }^{3}$, Iran

Received in March 2011

CrossChecked in May 2011

Accepted in July 2011

\begin{abstract}
The aim of this study was to assess the volume of airborne fungi in the indoor and outdoor environment of poultry and cattle houses in the Mazandaran Province in Iran. Indoor and outdoor air of twenty cattle houses and twenty-five poultry houses were sampled using a single-stage impactor, which draws air at 20 $\mathrm{L} \min ^{-1}$ and impacts sampled material onto Petri plates containing malt extract agar. The plates were incubated at $30^{\circ} \mathrm{C}$ for seven days, after which the resulting colonies were counted. The fungi were identified and counted microscopically and macroscopically. A total of 4,662 fungal colonies were isolated from 90 plates collected from indoor and outdoor air of cattle and poultry houses. Cladosporium (55.3\%), yeast $(10.0 \%)$, and Aspergillus $(9.4 \%)$ were the most common findings. The concentration of airborne fungi in cattle and poultry houses ranged from $10 \mathrm{CFU} \mathrm{m}^{-3}$ to $1700 \mathrm{CFU} \mathrm{m}^{-3}$ in indoor and $10 \mathrm{CFU} \mathrm{m}^{-3}$ to $2170 \mathrm{CFU} \mathrm{m}^{-3}$ in outdoor environments. Cladosporium had the highest mean indoor ( $\left.424.5 \mathrm{CFU} \mathrm{m}^{-3}\right)$ and outdoor $\left(449.7 \mathrm{CFU} \mathrm{m}^{-3}\right)$ air concentration in the cattle houses. In the poultry houses, the highest mean concentrations were measured for Cladosporium $\left(551.0 \mathrm{CFU} \mathrm{m}{ }^{-3}\right)$ outdoors and yeast $\left(440.7 \mathrm{CFU} \mathrm{m}^{-3}\right)$ indoors. These levels might present an occupational risk, but threshold levels for these environments have yet to be established worldwide.
\end{abstract}

KEY WORDS: Aspergillus, Cladosporium, occupational risk, threshold levels, yeast

Fungi are a large group of organisms naturally occurring in soil, air, water, and various organic materials. Several fungal genera have been shown to cause allergy, such as Aspergillus, Alternaria, and Cladosporium (1-4). A large number of fungi produce mycotoxins and/or secondary metabolites and volatile organic compounds that can affect human and animal health (5-8). In susceptible or highly-exposed individuals these can lead to invasive mycosis (9).
Many studies have shown that human exposure to airborne dust and microorganisms such as bacteria and fungi can cause respiratory diseases (10-13). Indoor air of cattle and poultry houses can be an important source of fungi (14-16) and involve high risk of occupational exposure. Epidemiological studies have confirmed an increased prevalence of respiratory symptoms and adverse changes in the pulmonary function of poultry workers $(17,18)$. 
Mazandaran is a northern province of Iran located on the southern coast of the Caspian Sea. In the coastal plains - where we conducted our study - the humidity is high and climate temperate, favouring fungal growth and spread through air.

\section{MATERIAL AND METHODS}

\section{Sampling sites}

Twenty cattle houses and twenty-five poultry houses were randomly selected from across the coastal plains of the Mazandaran Province. Indoor and outdoor air samples were collected in the winter of 2011. We also collected indoor air samples from ten public places and households for control.

\section{Air sampling and laboratory analysis}

Air samples were taken with a SKC standard single-stage impactor (SKC Inc., UK), which draws air at $20 \mathrm{~L} \mathrm{~min}^{-1}$ through a stage with 400 holes and impacts the sampled material onto $90-\mathrm{mm}$ diameter Petri dishes containing malt extract agar (Merck, Darmstadt, Germany). For each sample, $100 \mathrm{~L}$ of air were aspirated at a height of $\sim 150 \mathrm{~cm}$ above the floor. The air sampler sieve plate was cleaned with $10 \%$ formalin prior to sampling.

The Petri plates were incubated at $30{ }^{\circ} \mathrm{C}$ for seven days, after which the resulting colonies were counted. The fungi were identified by both microscopic and macroscopic observation. Fungi that could not be identified were sub-cultured on potato dextrose agar (QUELAB, Montreal, Canada), water agar (Bacto agar, USA), and/or slide cultures for further study.

\section{Data analysis}

We used positive-hole correction (19) to correct the counts of colony-forming units (CFU) for the limited number of impaction sites on the plate. We then used the following formula to get $\mathrm{CFU}$ per cubic meter:

$C F U \mathrm{~m}^{-3}=\frac{\text { Positive hole corrected } C F U}{\text { Time sampled }} \times \frac{1 \mathrm{~min}}{\text { Sampling rate }(\mathrm{L})} \times \frac{1000 \mathrm{~L}}{1 \mathrm{~m}^{3}}$

\section{RESULTS}

A total of 100 impacted plates were collected, of which 55 were indoor air samples and 45 outdoor.
Ninety plates turned out positive. A total of 12 genera of fungi from the indoor and 13 genera from the outdoor air samples were identified from the cattle and poultry houses. Eighty-three plates were positive to Cladosporium, 59 to Aspergillus, and 51 to Alternaria. Phoma, Trichoderma, Curvularia, and Ulocladium had one positive plate each.

A total of 4662 fungal colonies were grown on the 90 positive plates impacted by indoor and outdoor air samples taken from cattle and poultry houses. The most common were Cladosporium (55.3\%), yeast (10.0\%), and Aspergillus (9.4\%). Cladosporium (63.8\%), Aspergillus (13.5\%), and Penicillium $(12.9 \%)$ were the most frequent in indoor air of control places.

Table 1 shows the concentration of airborne fungi in outdoor and indoor air of cattle and poultry houses and control places from Mazandaran Province, Iran. It ranged from $10 \mathrm{CFU} \mathrm{m} \mathrm{m}^{-3}$ to $1700 \mathrm{CFU} \mathrm{m} \mathrm{m}^{-3}$ indoors and from $10 \mathrm{CFU} \mathrm{m}^{-3}$ to $2170 \mathrm{CFU} \mathrm{m}^{-3}$ outdoors (not shown in Table 1). The highest mean concentration in indoor and outdoor air of cattle houses was found for Cladosporium (424.5 $\mathrm{CFU} \mathrm{m}^{-3}$ and $449.7 \mathrm{CFU} \mathrm{m}^{-3}$, respectively). In poultry houses, yeast (440.7 CFU $\mathrm{m}^{-3}$ ) had the highest indoor and Cladosporium $\left(551.0 \mathrm{CFU} \mathrm{m}^{-3}\right)$ the highest outdoor mean concentration.

The highest mean concentrations in control places were found for Cladosporium (683.0 $\mathrm{CFU} \mathrm{m}^{-3}$ ), Penicillium (143.7 $\mathrm{CFU} \mathrm{m}^{-3}$ ), and Aspergillus $\left(143.4 \mathrm{CFU} \mathrm{m}^{-3}\right)$.

\section{DISCUSSION}

Occupational environments with high temperature humidity and organic material levels such as poultry and cattle houses favour fungal growth and release of spores. The involved risk of adverse effects on the health of workers and animals has been addressed by a number studies from different countries $(10,20$ 23).

Our finding that Cladosporium, yeast and Aspergillus were the most prevalent fungi in cattle and poultry houses is in line with some studies $(20,24)$. Other researchers $(10,15,23,25)$ reported the dominance of Aspergillus and Penicillium in indoor air of cattle or poultry houses, while Cladosporium ranked below these genera. Differences between these findings may be due to different sampling methods, different sampling seasons, different geographical 
conditions, and different culture media. For instance, Khattab and Levetin (26) have shown that the concentration of airborne fungal spores is also related to sampling height. Concentrations of some types of airborne fungal spores were higher at the ground level than at the ceiling level.

In contrast to cattle and poultry environment, yeast in indoor air of control places such as mosques, households, and schools had the lowest prevalence while Cladosporium, Aspergillus, and Penicillium prevailed. Our previous study (27) and some other studies from different countries (28-31) have also shown that Cladosporium, Aspergillus, and Penicillium are common in indoor and outdoor air of human dwellings. Of all observed environments, yeast had one the highest occurrences indoors of poultry houses (48 \%) (Table 1).

Indoor air fungal concentrations in our study are significantly lower than in some other studies $(13,21$, $23,33)$. Our study was conducted in the winter, when the concentrations of fungal spores are usually lower, because of the most fungi cannot grow and sporulate properly at lower temperatures, which drop even in indoor environments (14). Matković et al. (33) suggested that the total fungal count in barn air depends on animal species, housing conditions, and animal feeding and grooming. Ventilation system can also play an important role in indoor environment. Investigators from different countries who used sampling methods similar to ours have reported diverse concentration ranges of airborne fungi in cattle and poultry houses $(10,15,20-23)$. This may be due to variations in climate, season, and sampling time.

Our results show an obvious increase in mean Scopulariopsis CFU in indoor air of cattle and poultry houses compared to outdoor air. Similar results were seen for Fusarium and Trichoderma in cattle houses and for Ulocladium in poultry houses, even though Trichoderma and Ulocladium were isolated from one collected sample each. We cannot offer an explanation for these differences, but they may be related to indoor conditions of poultry and cattle houses. The reason for differences in the Fusarium levels seems to be more obvious. Fusarium is a grain-associated fungus and grain is used indoors as feed for both poultry and cattle.

According to other authors $(28,34-36)$ and our previous study (27), general outdoor environments usually have higher levels of airborne fungi than indoor places. In addition, outdoor levels highly contribute to concentrations indoors (37). In our study, airborne fungi had higher concentrations outdoors of

Table 1 Concentrations of airborne fungi indoors and outdoors of cattle and poultry houses and control places in Mazandaran Province, Iran

\begin{tabular}{|c|c|c|c|c|c|c|c|c|c|c|c|c|c|c|c|}
\hline \multirow{4}{*}{ Fungi } & \multicolumn{15}{|c|}{ Concentration / CFU m ${ }^{-3}$} \\
\hline & \multicolumn{6}{|c|}{$\begin{array}{l}\text { Cattle houses } \\
(\mathrm{n}=20)\end{array}$} & \multicolumn{6}{|c|}{$\begin{array}{l}\text { Poultry houses } \\
\quad(n=25)\end{array}$} & \multirow{2}{*}{\multicolumn{3}{|c|}{$\begin{array}{c}\begin{array}{c}\text { Control places } \\
(\mathrm{n}=10)\end{array} \\
\text { Indoor }\end{array}$}} \\
\hline & \multicolumn{3}{|c|}{ Indoors } & \multicolumn{3}{|c|}{ Outdoors } & \multicolumn{3}{|c|}{ Indoors } & \multicolumn{3}{|c|}{ Outdoors } & & & \\
\hline & $\mathbf{N}$ & Total & Mean & $\mathbf{N}$ & Total & Mean & $\mathrm{N}$ & Total & Mean & $\mathbf{N}$ & Total & Mean & $\mathbf{N}$ & Total & Mean \\
\hline Cladosporium & 16 & 6792 & 424.5 & 19 & 8545 & 449.7 & 23 & 5438 & 236.4 & 15 & 8265 & 551.0 & 10 & 6830 & 683.0 \\
\hline Aspergillus & 14 & 932 & 66.6 & 11 & 780 & 70.9 & 18 & 2318 & 128.6 & 6 & 747 & 124.5 & 10 & 1434 & 143.4 \\
\hline Penicillium & 13 & 726 & 55.8 & 11 & 1322 & 120.2 & 14 & 825 & 58.9 & 2 & 203 & 101.5 & 9 & 1293 & 143.7 \\
\hline Fusarium & 5 & 712 & 142.4 & 6 & 261 & 43.5 & 4 & 151 & 37.7 & 7 & 332 & 47.4 & 3 & 50 & 16.7 \\
\hline Alternaria & 9 & 464 & 51.5 & 9 & 567 & 63.0 & 16 & 623 & 38.9 & 9 & 270 & 30.0 & 8 & 483 & 60.4 \\
\hline Yeast & 2 & 194 & 97.0 & 3 & 256 & 85.3 & 12 & 5288 & 440.7 & 5 & 1885 & 377.0 & 1 & 30 & 30.0 \\
\hline Sterile hyphae & 8 & 170 & 21.2 & 6 & 120 & 20.0 & 12 & 412 & 34.3 & 8 & 351 & 43.9 & 7 & 291 & 41.6 \\
\hline Trichoderma & 1 & 81 & 81.0 & - & - & - & - & - & - & - & - & - & - & - & - \\
\hline Scopulariopsis & 2 & 80 & 40.0 & - & - & - & 12 & 2706 & 225.5 & 2 & 121 & 61.5 & 1 & 30 & 30.0 \\
\hline Rhizopus & 4 & 50 & 12.5 & 5 & 50 & 10.0 & - & - & - & 5 & 60 & 12.0 & - & - & - \\
\hline Mucor & 1 & 30 & 30.0 & 1 & 40 & 40.0 & - & - & - & - & - & - & - & - & - \\
\hline Ulocladium & - & - & - & - & - & - & 1 & 81 & 81.0 & - & - & - & - & - & - \\
\hline Unidentified & - & - & - & - & - & - & - & - & - & - & - & - & 1 & 71 & 71.0 \\
\hline Curvularia & - & - & - & 1 & 20 & 20.0 & - & - & - & - & - & - & - & - & - \\
\hline Phoma & - & - & - & - & - & - & - & - & - & 1 & 10 & 10.0 & - & - & - \\
\hline
\end{tabular}

$n$ - number of samples

$N$-number of positive samples 
cattle houses than indoors, but the reverse is true for poultry houses. This may be owed to a substantial presence of fungal growth substrates inside the poultry houses.

Cattle and poultry houses are considered occupational environments with high levels of exposure to fungi. Indoor exposure levels are usually much higher than outdoor levels, which seldom exceed $10^{4}$ spores per cubic meter (38). Activities in these indoor places such as cleaning and feeding animals increase occupational risk of exposure to airborne microorganisms. Spores of some type of fungi including Cladosporium, Aspergillus, Penicillium and Alternaria may carry allergens, antigens, polysaccharides such as the $\beta(1 \rightarrow 3)$-glucans, and mycotoxins and can cause allergic respiratory disease in susceptible individuals. However, no guidelines or limit values for fungal concentrations in occupational or non-occupational environments have been set by now. A comprehensive review by Eduard (38) suggests that each fungal type should have its own limit set, as different fungal concentrations are needed for different types of fungi to cause a related syndrome in exposed workers.

The most common species in our study Cladosporium, Aspergillus, Penicillium, and Alternaria are strongly associated with allergic respiratory disease, especially asthma. Aspergillus and Fusarium are also important producers of mycotoxins and/or secondary metabolites and volatile organic compounds in nature. In addition, all of the above mentioned fungal genera can cause invasive mycosis in susceptible individuals or those exposed to extremely high levels.

Our study has determined airborne fungal levels that might present occupational risk of respiratory diseases.

\section{Acknowledgment}

This work was supported by grants from the Mazandaran University of Medical Sciences.

\section{REFERENCES}

1. Bowyer P, Fraczek M, Denning DW. Comparative genomics of fungal allergens and epitopes shows widespread distribution of closely related allergen and epitope orthologues. BMC Genomics 2006;7:251.

2. Simon-Nobbe B, Denk U, Schneider PB, Radauer C, Teige M, Crameri R, Hawranek T, Lang R, Richter K, Schmid-
Grendelmeier P, Nobbe S, Hartl A, Breitenbach M. NADPdependent mannitol dehydrogenase, a major allergen of Cladosporium herbarum. J Biol Chem 2006;281:1635460.

3. Black PN, Udy AA, Brodie SM. Sensitivity to fungal allergens is a risk factor for life-threatening asthma. Allergy 2000;55:501-4.

4. Sanchez H, Bush RK. A review of Alternaria alternata sensitivity. Rev Iberoam Micol 2001;18:56-9.

5. Hedayati MT, Pasquallotto AC, Warn PA, Bowyer P, Denning DW. Aspergillus flavus: human pathogen, allergen and mycotoxin producer. Microbiology 2007;153:1677-92.

6. Kim JL, Elfman L, Mi Y, Wieslander G, Smedje G, Norbäck D. Indoor molds, bacteria, microbial volatile organic compounds and plasticizers in schools - associations with asthma and respiratory symptoms in pupils. Indoor Air 2007;17:153-63.

7. Bush RK, Portnoy JM, Saxon A, Terr AI, Wood RA. The medical effects of mold exposure. J Allergy Clin Immunol 2006;117:326-33.

8. Richard JL. Some major mycotoxins and their mycotoxicoses - an overview. Int J Food Microbiol 2007;119:3-10.

9. Pfaller MA, Diekema DJ. Epidemiology of invasive mycoses in North America. Crit Rev Microbiol 2010;36:1-53.

10. Lugauskas A, Krikštaponis A, Šveistyté L. Airborne fungi in industrial environments - potential agents of respiratory diseases. Ann Agric Environ Med 2004;11:19-25.

11. Rusca S, Charrière N, Droz PO, Oppliger A. Effects of bioaerosol exposure on work-related symptoms among Swiss sawmill workers. Int Arch Occup Environ Health 2008;81:41521.

12. Skorge TD, Eagan TM, Eide GE, Gulsvik A, Bakke PS. Indoor exposures and respiratory symptoms in a Norwegian community sample. Thorax 2005;60:937-42.

13. Rimac D, Macan J, Varnai VM, Vučemilo M, Matković K, Prester Lj, Orct T, Trošić I, Pavičić I. Exposure to poultry dust and health effects in poultry workers: impact of mould and mite allergens. Int Arch Occup Environ Health 2010;83:9-19.

14. Lee SA, Adhikari A, Grinshpun SA, McKay R, Shukla R, Reponen T. Personal exposure to airborne dust and microorganisms in agricultural environments. J Occup Environ Hyg 2006;3:118-30.

15. Abd-Elall AM, Mohamed ME, Awadallah MA. Potential airborne microbial hazards for workers on dairy and beef cattle farms in Egypt. Vet Ital 2009;45:275-85.

16. Jo WK, Kang JH. Exposure levels of airborne bacteria and fungi in Korean swine and poultry sheds. Arch Environ Occup Health 2005;60:140-6.

17. Radon K, Weber C, Iversen M, Danuser B, Pedersen S, Nowak D. Exposure assessment and lung function in pig and poultry farmers. Occup Environ Med 2001;58:405-10.

18. Rylander R, Carvalheiro MF. Airways inflammation among workers in poultry houses. Int Arch Occup Environ Health 2006;79:487-90.

19. Andersen A. New sampler for the collection sizing, and enumeration of viable airborne particles. J Bacteriol 1958;76:471-84.

20. Alvarado CS, Gandara A, Flores C, Perez HR, Green CF, Hurd WW, Gibbs SG. Seasonal changes in airborne fungi and bacteria at a dairy cattle concentrated animal feeding 
operation in the southwest United States. J Environ Health 2009;71:40-4.

21. Adhikari A, Sen MM, Gupta-Bhattacharya S, Chanda S Volumetric assessment of airborne fungi in two sections of a rural indoor dairy cattle shed. Environ Int 2004;29:10718

22. Wilson SC, Morrow-Tesch J, Straus DC, Cooley JD, Wong WC, Mitlöhner FM, McGlone JJ. Airborne microbial flora in a cattle feedlot. Appl Environ Microbiol 2002;68:323842.

23. Matković K, Vučemilo M, Vinković B. Airborne fungi in dwellings for dairy cows and laying hens. Arh Hig Rada Toksikol 2009;60:395-9.

24. Wang Y, Lu G, Zhang X, Ma R, Chai T. Biodiversity and concentration of airborne fungi in chicken house. In: Aland A, editor. Animal health, animal welfare and biosecurity. Proceedings of $13^{\text {th }}$ International Congress in Animal Hygiene; 17-21 June 2007; Tartu, Estonia. Tartu: Estonia University of Life Sciences; 2007. p. 564-70.

25. Karwowska E. Microbiological air contamination in farming environment. Polish J Environ Studies 2005;14:445-9.

26. Khattab A, Levetin E. Effect of sampling height on the concentration of airborne fungal spores. Ann Allergy Asthma Immunol 2008;101:529-34.

27. Hedayati MT, Mayahi S, Aghili R, Goharimoghadam K Airborne fungi in indoor and outdoor of asthmatic patients' home, living in the city of sari. Iran J Allergy Asthma Immunol 2005;4:189-91.

28. Sen B, Asan A. Fungal flora in indoor and outdoor air of different residential houses in Tekirdag City (Turkey): seasonal distribution and relationship with climatic factors. Environ Monit Assess 2009;151:209-19.

29. Gonianakis MI, Neonakis IK, Gonianakis IM, Baritaki MA, Bouros D, Potamias G, Kontou-Fili KS. Mold allergy in the
Mediterranean Island of Crete, Greece: a 10-year volumetric, aerobiological study with dermal sensitization correlations. Allergy Asthma Proc 2006;27:354-62.

30. Chadeganipour M, Shadzi S, Nilipour S, Ahmadi G. Airborne fungi in Isfahan and evaluation of allergenic responses of their extracts in animal model. Jundishapur J Microbiol 2010;3:155-60

31. Cetinkaya Z, Fidan F, Unlu M, Hasenekoglu I, Tetik L, Demirel R. Assessment of indoor air fungi in WesternAnatolia, Turkey. Asian Pac J Allergy Immunol 2005;23:8792.

32. Obire O, Anyanwu EC, Okigbo RN. Saprophytic and crude oil degrading fungi from cow dung and poultry droppings as bioremediating agents. J Agric Technol 2008;4:81-9.

33. Matković K, Vučemilo M, Vinković B, Pavičić Ž, Matković $\mathrm{S}$, Benić M. Airborne fungi in a dairy barn with emphasis on microclimate and emissions. Vet arhiv 2009;79:207-18.

34. Lee T, Grinshpun SA, Martuzevicius D, Adhikari A, Crawford CM, Reponen T. Culturability and concentration of indoor and outdoor airborne fungi in six single-family homes. Atmos Environ 2006;40:2902-10.

35. Pei-Chih W, Huey-Jen S, Chia-Yin L. Characteristics of indoor and outdoor airborne fungi at suburban and urban homes in two seasons. Sci Total Environ 2000;253:111-8.

36. Shelton BG, Kirkland KH, Flanders WD, Morris GK. Profiles of airborne fungi in buildings and outdoor environments in the United States. Appl Environ Microbiol 2002;68:174353.

37. Burge H. Bioaerosols: prevalence and health effects in the indoor environment. J Allergy Clin Immunol 1990;86:687701.

38. Eduard W. Fungal spores: a critical review of the toxicological and epidemiological evidence as a basis for occupational exposure limit setting. Crit Rev Toxicol 2009;39:799-864. 


\section{Sažetak} VOLUMETRIJSKI NALAZI LEBDEĆIH SPORA GLJIVICA U UNUTRAŠNJOSTI I IZVAN
PERADARNIKA I STAJA U IRANSKOJ PROVINCIJI MAZANDARAN

Cilj je ovog ispitivanja bio utvrditi razine gljivica u zraku u unutrašnjosti i izvan peradarnika i staja u iranskoj provinciji Mazandaran. Uzeti su uzorci zraka iz unutrašnjosti i izvan prostora dvadeset staja i dvadeset i pet peradarnika s pomoću jednostupanjskog impaktora s protokom zraka od $20 \mathrm{~L} \mathrm{~min}^{-1}$. Uzorkovan je zrak impaktiran na Petrijeve pločice s hranjivom podlogom od ekstrakta slada. Pločice su inkubirane sedam dana na $30^{\circ} \mathrm{C}$, a zatim su izolirane i prebrojene dobivene kolonije mikroskopski i makroskopski. Ukupno su izolirane 4.662 kolonije s 90 pločica. Najčešće su bile gljivice Cladosporium (55,3\%), kvasac $(10,0 \%)$ i Aspergillus $(9,4 \%)$. Koncentracije gljivica nošenih zrakom kretale su se od $10 \mathrm{CFU} \mathrm{m}^{-3}$ do $1.700 \mathrm{CFU} \mathrm{m} \mathrm{m}^{-3} \mathrm{u}$ unutrašnjosti staja i peradarnika te od $10 \mathrm{CFU} \mathrm{m}^{-3}$ do $2.170 \mathrm{CFU} \mathrm{m}^{-3}$ izvan njih. Najviša srednja koncentracija u unutrašnjosti $\left(424,5 \mathrm{CFU} \mathrm{m}^{-3}\right)$ i izvan staja $(449,7 \mathrm{CFU} \mathrm{m}-3)$ izmjerena je za Cladosporium. U peradarnicima najviše su srednje koncentracije u unutrašnjosti i izvan njih izmjerene za Cladosporium $\left(551,0 \mathrm{CFU} \mathrm{m}^{-3}\right) \mathrm{i}$ kvasac $\left(440,7 \mathrm{CFU} \mathrm{m}^{-3}\right)$. Te koncentracije mogu biti povezane s rizikom od profesionalnih respiracijskih bolesti, ali još uvijek nisu utvrđene gornje dopuštene razine za ovu vrstu okoliša bilo gdje u svijetu.

KLJUČNE RIJEČI: Aspergillus, Cladosporium, gornje dopuštene razine, kvasac, profesionalne respiracijske bolesti

\section{CORRESPONDING AUTHOR:}

Mohammad T. Hedayati

Department of Medical Mycology and Parasitology

School of Medicine, Km 18 Khazarabad Road

P.O. Box: 48175-1665, Sari, Iran

E-mail:m.t.hedayati@hotmail.com 